\title{
The CAP Dualism-Efficiency or Competition
}

ISSN: 2637-7659

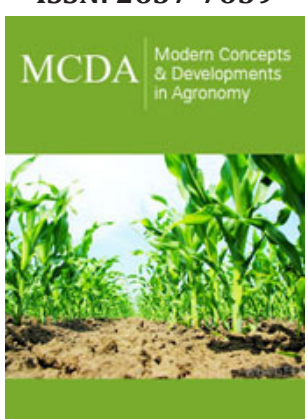

*Corresponding author: Minko Georgiev, Department of Economics, Agricultural University, Plovdiv, Bulgaria

Submission: 眥 August 12, 2019

Published: 海August 12, 2019

Volume 5 - Issue 1

How to cite this article: Minko Georgiev. The Cap Dualism-Efficiency or Competition. Mod Concep Dev Agrono.5(1). MCDA.000601.2019. DOI: 10.31031/MCDA.2019.05.000601

Copyright@ Minko Georgiev, This article is distributed under the terms of the Creative Commons Attribution 4.0 International License, which permits unrestricted use and redistribution provided that the original author and source are credited.

\author{
Minko Georgiev* \\ Department of Economics, Bulgaria
}

Opinion

The Common Agricultural Policy of the EU (CAP) contains incentives for consolidation of resources and integration of organizations. The entire CAP follows the concept of efficiency achieved through product structure optimization and economies of scale. CAP imposes an advantage for the concept of efficiency at each level of the economic system. For this reason, integration-horizontal and vertical [1]-has been imposed as more important for farmers than competition. Such an approach stimulates large-scale exchange and consolidation of resources, at the same time being a prerequisite for problems for market competition. The Chicago School addresses the concept of efficiency in relation to the "antitrust paradox" [2]. Harvard authors propose that the "leverage effect" [3] can occur as a result of efficiency, meaning that the related markets could be influenced by some market players, and therefore discrimination against other subjects can emerge. Another way to achieve higher economies of scale is horizontal integration. Practically, however, in the course of resource exchange, certain actors can be excluded from the economic organization. The type of organizational structure determines the way of resource distribution and it is essential for competition. A critical analysis of the collision between competition and integration has been offered by Glick M [4]. Actually, efficiency may turn out to be in a conflict with competition [5].

The current discussion is focused on how the CAP rules and economic doctrine, and their transposed effects in Bulgaria creating efficiency through integration of organizations and consolidation of the agricultural land resource, can lead to problems for competition due to:

A. Contradiction between CAP objectives in EU primary law;

B. Subsidies and financing regulations in agriculture;

C. Regulations on the integration of production organizations and processes in agriculture;

D. Regulations on the consolidation of agricultural land;

E. Indirect support for large-scale entities in agriculture.

Priority is systematically granted to the CAP objective on efficiency over the objective related to market stability (TFEU, Art. 39 (a) and (c)). This shifts the focus towards efficiency, stimulates market bilaterality and incorrectly relies solely on the belief that efficiency always creates and brings greater added value to consumers. Subsidies granted due to land consolidation play the role of an incentive for some of the players to turn the receiving of these subsidies into sustainable economic rents. Such players are actually rent-seekers who, even when they produce goods, do not transfer higher value to consumers. This may be interpreted as another proof that the antitrust paradox is not valid within the CAP. The subsidies granted under the Bulgarian conditions-the leading grounds being the consolidation of property-may lead not only to deformations in the concept of efficiency, but also to uncontrolled obtaining of property. This way of receiving subsidies is a prerequisite for the "land grabbing" processes. Land grabbing lies at the basis of the establishment of few market players possessing great market power at a local level. Efficiency begins to interfere with competition. In producers' associations antitrust restrictions exist on the agreements of entities on product prices and on the membership terms. However, there are no antitrust measures regarding the access to resources (especially the primary production factor-agricultural land). A problem arises when the governing bodies of an organization protect personal interests, deforming for their own purposes the institute of representation. The combination of individual and common, 
as well as private and state functions, transforms the power in organizations. Thus, these organizations in EU agriculture could represent a mechanism for obtaining an internal advantage that is capitalized by certain individual subjects. I.e., such subjects either gain market power or the ability to transfer costs to other participants on agricultural markets.

When the resource is fragmented, this leads to both higher production and transaction costs. As already discussed, this has become the reason for the CAP to create prerequisites for constantly increasing efficiency through production and organisational economies of scale. The ultimate outcome is unfortunately often unwanted: concentration and agricultural land grabbing have become a fact in the country. Some non-market "substitutions" (market principles are replaced by administrative procedures) within the national legislation also contribute to this. If we review the market processes in agricultural land, it is observed that

A. the types of represented actors increase-administrative bodies replace market actors;

B. a transition is made from complete contracts to incomplete ones, e.g. the purchase of agricultural land is substituted by land use; the sales of land-by lease;

C. transparency is substituted by formal procedures which increase asymmetry levels. In practice, this leads to an increase in the number of large companies and a decrease in the number of small farmers.

Eventually, the total number of market participants is reduced. This is another evidence of the fact that the existing consolidation rules gradually form a bilateral market. The Bulgarian legislation provides for the opportunity for large trusts to acquire and manage ownership over agricultural land in the country and abroad. These companies have certain tax privileges which, along with their capacity for diversification, can be construed as a form of indirect support. The shareholders of such companies can transform their subject of activity by encompassing simultaneously the agricultural sector and industry. These acquisitions have led to a significant reduction of the number of agricultural land owners on both national and local levels. According to data obtained through own research, the number of these trusts on the agricultural land market in Bulgaria has been cut from 67 to 6 following the accession to the EU. Currently, only two companies control over half of the cultivated agricultural land. On the other hand, indirect advantages are also found on a local level in agricultural land acquisition and management processes. Such an example is represented by the functioning consolidation procedure under Art. 37 (c) of the Agricultural Land Ownership and Use Act (ALOUA). According to it, the cultivation of owned or leased agricultural land should be declared by the owners or users. If a declaration is not timely submitted, the producers are automatically excluded from the market and lose access to their property for a period of one year. The intentionally established through the legislation information asymmetry creates prerequisites for non-market advantages. Nonmarket allocation shifts resources towards large-scale agricultural producers. The question arises whether a balance between the efficiency and competition doctrines is possible.

\section{References}

1. Hovenkamp H (2010) Harvard, Chicago, and transaction cost economics in antitrust analysis. The Antitrust Bulletin 55(3): 613-662.

2. Bork R (1978) The antitrust paradox: A Policy at War with Itself. JSTOR 127(1): 273-282.

3. Robinson J (1933) The economics of imperfect competition. Palgrave Macmillan, New York, USA.

4. Glick M (2019) Antitrust and economic history: The historic failure of the Chicago school of antitrust. Institute for New Economic Thinking, New York, USA.

5. Posner R (1978) Antitrust Law: An Economic Perspective. Chicago: The University of Chicago Press, Chicago, Illinois, USA. 